\title{
Party prohibition cases: different approaches by the Turkish constitutional court and the European Court of Human Rights
}

\author{
Ergun Özbudun*
}

\author{
Centre for Studies in Society and Politics, Bilkent University, Ankara, Turkey
}

(Received 28 March 2009; final version received 20 August 2009)

\begin{abstract}
The article deals with the different approaches followed by the Turkish Constitutional Court and the European Court of Human Rights (ECtHR) in party prohibition cases. The Turkish Constitution and even more so the Law on Political Parties contain a long list of party bans, the violation of which leads to the closure of the party by the Constitutional Court. The Turkish Constitutional Court, both under the 1961 and the 1982 Constitutions, interpreted these provisions in an exceedingly illiberal manner, and has so far closed down a total of 24 political parties. Turkish rules and practices concerning the prohibition of political parties are among the most important 'democracy deficits' of the Turkish political system. In the article, the Turkish Court's illiberal approach to party prohibition cases, especially those involving the protection of the national and territorial integrity of the state and of the principle of secularism, is compared with the much more liberal criteria developed by the ECtHR and the Venice Commission.
\end{abstract}

Keywords: Turkey; party; constitutional court; military; human rights

\section{Introduction}

This article aims to compare the different approaches followed by the Turkish Constitutional Court and the European Court of Human Rights (ECtHR) in party prohibition cases. The article shows that while the former pursues an 'ideology-based' approach putting emphasis on the interests of the state as it perceives them, the latter maintains a 'rights-based' approach considering the free operation of political parties as one of the indispensable conditions of a free democratic order. The illiberal approach of the Turkish Court is demonstrated to be mainly a function of the basic philosophy of the 1982 Constitution.

It is generally agreed that the Turkish Constitution of 1982, the product of a military coup, still retains many of the authoritarian, statist, and tutelary characteristics that reflect the mentality of its military founders. Although the 15 amendments that the Constitution has undergone since 1987 has democratized and

\footnotetext{
*Email: ergun.ozbudun@gmail.com 
liberalized it to a considerable degree, it has not been possible to completely eliminate some of its birth defects. Thus, one of the most important areas of remaining democratic deficits concerns the low level of protection granted to political parties. Both the 1961 and the 1982 Constitutions embraced the concept of so-called 'militant democracy', but the latter went much further in that direction than its predecessor, as will be spelled out below.

The situation is further aggravated by the fact that the long list of prohibitions contained in the Constitution, and an even a longer one in the Law on Political Parties, have been implemented with excessive zeal and rigidity by the Turkish Constitutional Court. It has been convincingly argued that in matters concerning political party freedom, the Turkish Court has followed an 'ideology-based' approach rather than a 'rights-based' approach. 'While the liberal paradigm gives priority to individuals and their rights ... the "ideology-based" paradigm favours the state and society over the individual ... The Turkish Constitutional Court has adopted an "ideology-based" paradigm in deciding political party cases. This paradigm reflects a positivist, one-dimensional, monolithic, and authoritarian outlook. ${ }^{1}$

Surely, Turkey is not the only European country that has been inspired by the concept of militant democracy. However, while party closures are extremely rare in such countries, the Turkish Constitutional Court has closed down six parties under the 1961 Constitution, and 18 parties under the 1982 Constitution. Most of these rulings were based on the alleged violation of the constitutional provisions protecting the indivisible national and territorial integrity of the state or its secular character.

To elucidate the root causes of the difference between the 'ideology-based' approach of the Turkish Court and the much more liberal, 'rights-based' jurisprudence of the European Court of Human Rights (ECtHR) and of the principal European Constitutional Courts requires an in-depth analysis of the Turkish political system, beyond the scope of this study. It suffices to say here that the founding philosophy of the Republic (i.e., Kemalism) strongly stressed the principles of a unitary, national, and secular state. These values have been deeply internalized by the judiciary as well as by other sectors of the state elites such as the military. Thus, in the words of a leading Turkish constitutional scholar:

ever since the establishment of the Republic of Turkey, the Turkish legal complex has been mobilised to consolidate the regime by both eliminating the potential threats and providing legal justifications for the authoritarian behaviour of the regime. Thus the legal complex has functioned as part and parcel of both the repressive and ideological state apparatus, to use Althusser's terms. The Turkish legal complex, the judiciary at its centre, has consistently sought to align itself with the ruling stratum of the Republic, namely the military and civilian bureaucracy. The liberalization of the regime has been a process which involves a political struggle between the state elites and the political elites. In this struggle, the judiciary alongside the military appears to be one of the most conservative state apparatuses that resist the liberalization and democratization of the legal and political life of the country. ${ }^{2}$ 
Although both the 1961 and the 1982 Turkish Constitutions recognized political parties as 'indispensable elements of the democratic political life', they did not provide an unlimited freedom for political parties. ${ }^{3}$ Under Article 57 of the 1961 Constitution, 'the statutes, programs and activities of political parties shall conform to the principles of democratic and secular Republic based on human rights and freedoms, and to the basic provision of the integrity of the State with its territory and nation. Parties that do not conform to them shall be permanently closed down'. Similarly, Article 68 of the 1982 Constitution as amended in 1995 states that:

the statutes, programs, and actions of political parties shall not be contrary to the independence of the State, its indivisible integrity with its territory and nation, human rights, the principles of equality and the rule of law, national sovereignty, the principles of the democratic and laic Republic; they shall not aim to advocate or establish class or group dictatorship or any other kind of dictatorship; they shall not encourage the commitment of crimes.

These two articles, despite the differences in the languages, essentially protect the same fundamental values, namely the independence and the territorial and national integrity of the state, Republicanism, human rights, and a democratic and secular state. Certain concepts referred to in the text of the 1982 Constitution, such as equality and the rule of law, national sovereignty, and the prohibition of dictatorship, are already implied by the term 'democratic state', and are, therefore, unnecessary repetitions. Similarly, the prevention of incitement to crimes is a natural and fundamental function of any state.

According to the fifth and sixth paragraphs of Article of the 1982 Constitution, violations of these principles is a cause for the permanent prohibition of a political party. Paragraph 5 regulates the cases where such violations are committed through party statutes or programs. Paragraph 6 regulates the situations in which the party becomes a 'focus' of such anti-constitutional activities. In addition to the prohibitions stipulated by Article 68, under paragraph 10 of Article 69 'those political parties that receive financial aid from foreign states, international organizations, and real persons or legal personalities that are not of Turkish nationality shall be permanently closed down'. It may be argued that the 1995 amendments to Articles 68 and 69 of the Constitution represent a significant improvement in the status of

political parties compared to the original text of these articles. ${ }^{4}$ In the following pages, the main material criteria for prohibition, namely the protection of the territorial and national integrity of the state and of the principle of secularism, will be discussed with reference to the rulings of the Turkish Constitutional Court and the ECtHR. This will be followed by an analysis of the prohibition criteria developed by the ECtHR and the Venice Commission.

\section{The principle of the indivisible territorial integrity of the state}

The concept of the indivisible integrity of the state with its territory and nation should be analysed under two headings: the territorial integrity of the state and 
the national integrity of the state. The reflection of the constitutional provision protecting the territorial integrity of the state in the Law on Political Parties is Article 80 of the Law entitled 'The Protection of the Unitary Nature Of The State'. It is debatable whether this provision is a simple extension and concretization of the constitutional prohibition or a new prohibition beyond the mandate of the Constitution. It may be argued that the unitary state is not a necessary consequence of the principle of the territorial integrity of the state. Territorial integrity of the state can be reconciled with federal or regional forms of government. This view is supported by the fact that in most of the federal or regional states of the world, the territorial integrity of the state is under no serious threat. Therefore, this provision of the Law on Political Parties seem to contradict Article 68 of the Constitution. ${ }^{5}$

The Turkish Constitutional Court, however, interprets the territorial integrity of the state in a manner to protect the unitary nature of the state as well. Thus, the Court in its prohibition ruling concerning the Democracy Party stated that:

The principle of the indivisible integrity encompasses the protection of the independence and the territorial and national integrity of the state. This historical characteristic of the Turkish Republic, which has been a unitary state since its establishment, has been reflected in the Constitutions and strict sanctions have been provided for its protection ... This structure is the raison d'étre of the nation, and it cannot be compared with the conditions of other multi-national countries. No concessions can be made with regard to this fundamental principle ... The Constitution, which is based on the principle of unitary state, does not permit federal state. Therefore, political parties cannot include federal system in their programs, and cannot advocate such a structure ... As the principle of nation-state does not permit the notion of multi-national state, there is no room for a federal structure in such a system. In a federal system, (multiple) sovereignties are exercised by the federated states. Whereas, in a unitary state, there is only one sovereignty. ${ }^{6}$

In the same ruling, the Court precludes even regional states by stating that 'the Constitution is closed to such discriminatory procedures as autonomy or selfrule for regions', even though regional state is a variant of a unitary state. Furthermore, the Court commits another juridical error by arguing that in a federal state, federated states also exercise their sovereignties. Sovereignty, by its very nature, cannot be exercised by more than one unit. What the federated states exercise in a federal state is not sovereignty but a limited state power defined by the federal constitution. Another problem involves the Court's confusing multi-nationalism with federalism. Obviously, not all federal states are multi-national states. The Turkish Court reiterated the same reasoning in an earlier ruling concerning the Socialist Party. ${ }^{7}$

However, the European Court of Human Rights (ECtHR) ruled that the prohibition of the Socialist Party amounted to a violation of Article 11 of the European Convention of Human Rights. In its reasoning the ECtHR stated that:

having analysed Mr Perinçek's [the party leader] statements, the Court finds nothing in them that can be considered a call for the use of violence, an uprising or any other 
form of rejection of democratic principles. On the contrary, he stressed on a number of occasions the need to achieve the proposed political reform in accordance with democratic rules, through the ballot box and by holding referenda.

In the opinion of the Court, "the statements put forward a political programme with the essential aim being the establishment, in accordance with democratic rules, of a federal system in which Turks and Kurds would be represented on an equal footing and on a voluntary basis. Admittedly, reference is made to the right to self-determination of the 'Kurdish nation' and its right to 'secede'; however, read in their context, the statements using these words do not encourage secession from Turkey but seek rather to stress that the proposed federal system could not come about without the Kurds' freely given consent, which should be expressed through a referendum'. In an even more noteworthy passage, the Court argues that:

\begin{abstract}
the fact that such a political programme is considered incompatible with the current principles and structures of the Turkish State does not make it incompatible with the rules of democracy. It is of the essence of democracy to allow diverse political programmes to be proposed and debated, even those that call into question the way a State is currently organized, provided that they do not harm democracy itself. ${ }^{8}$
\end{abstract}

\title{
The principle of the indivisible national integrity of the state
}

The reflections of the constitutional principle of the national integrity of the state can be found in Articles 81, 82, and 83 of the Law on Political Parties (Law No. 2820, dated 22 April 1983). The most important of those which provided a basis for many prohibition rulings of the Constitutional Court is Article 81 entitled 'the prevention of creating minorities'. The Article stipulates that:

Political parties:

a) Cannot maintain that there are minorities in the territory of the Republic of Turkey, based on differences of national or religious culture, or race, or language.

b) Cannot pursue the aim or engage in activities to harm national unity by way of creating minorities in the territory of the Republic of Turkey through protecting, developing or spreading languages and cultures other than the Turkish language or culture.

c) Cannot use or distribute posters, placards, audio and video tapes, brochures and declarations written in languages other than Turkish in the writing and publishing of their statutes and programs, congresses, open or closed hall gatherings, public meetings and propaganda activities; nor can they remain indifferent to those actions perpetrated by others. However, their statutes and programs may be translated into a foreign language not prohibited by law.

In the same vein, Article 82 prohibits the pursuit of regionalism and racism, and Article 83 prohibits activities that would harm the principle of equality. It has 
long been maintained that Article 81 of the Law on Political Parties introduces a prohibition much beyond the constitutional mandate, and therefore is clearly unconstitutional. ${ }^{9}$ Indeed minorities, being sociological realities, cannot be superficially created by political parties, just as their denial by political parties does not make them disappear. The prohibition regarding the protection, development, and spreading of languages and cultures other than the Turkish language and culture reminds one of a 'cultural genocide' in the words of a leading Turkish constitutionalist. ${ }^{10}$

The Turkish Constitutional Court has interpreted the principle of the national integrity of the state in an extremely rigid manner in its prohibition rulings on a large number of parties. For example, in its decision concerning the Democracy Party, the Court asserted that:

The recognition of minority status based on differences of race and language is incompatible with the notion of territorial and national integrity. Just as citizens of other origins, the citizens of Kurdish origin are not prohibited from expressing their identity; it has been stipulated, however, that they are not a minority or a different nation, that they cannot be conceived outside the Turkish nation, and that they are placed in the integrity of the state. Citizens of Kurdish origin do not carry a characteristic conforming to the sociological and legal definitions of a minority; nor is there any legal rules that differentiates them from other citizens. It does not make any sense to transform unlimited rights into limited rights, and to transform being a nation itself into being a minority. It is clear that the aim is to accomplish secession ... One cannot violate the constitutional principle of national integrity by differentiating between Turkish and Kurdish nations. In the State of the Republic of Turkey, there is one state and one nation, not more than one nations. Even though there are individuals of different origins in the Turkish Nation, they are all placed in the unity of the Turkish Nation ... It is impossible to recognize validity to such dangerous aims derived from certain political causes and foreign factors ... and intensified by claims of human rights and freedom.

The relevant passage of the Constitutional Court's decision ends with the rather literary and emotional statement that 'the State is SINGLE; the territory is a WHOLE; the nation is ONE. ${ }^{11}$

These decisions of the Constitutional Court involve a number of highly debatable points. First of all, one may ask why the citizens of Kurdish origin do not conform to the 'sociological and legal definitions' of a minority. Sociologically speaking, a group of people who are different from the majority of population on the basis of language, race, religion, sect, or ethnicity, and are conscious of these differences, constitute a minority. Although there is no generally accepted definition of national minorities in the international human rights law, certain proposals put forward in this regard are not fundamentally different from this sociological definition. ${ }^{12}$ A second debatable point is the Court's argument that minority rights are inferior to the rights deriving from being a citizen of a nation-state. On the contrary, minority rights are those that are provided in addition to general citizenship rights with the aim of providing 'positive discrimination' for the members of minorities. ${ }^{13}$ Other controversial points in the Constitutional 
Court's ruling are the arguments equating the recognition of cultural rights for minorities with 'racism', maintaining that such claims have nothing to do with 'democratic and political rights', and asserting that they are influenced by 'foreign factors.'

There appears to be a fundamental difference between these decisions of the Constitutional Court and those of the ECtHR. The European Court in its ruling on the Freedom and Democracy Party (ÖZDEP) made frequent references to its earlier decision concerning the Socialist Party. The European Court reasons that 'having analysed ÖZDEP's programme, the Court finds nothing in it that can be considered a call for the use of violence, an uprising or any other form of rejection of democratic principles'. While the Court admits that:

\begin{abstract}
in its programme ÖZDEP also refers to the right to self-determination of the "national or religious minorities' ... taken in context, those words do not encourage people to seek separation from Turkey but are intended instead to emphasise that the proposed political project must be underpinned by the freely given, democratically expressed, consent of the Kurds ... Further, the Court has previously held that one of the principle characteristics of democracy is the possibility it offers of resolving a country's problems through dialogue, without recourse to violence, even when they are irksome. Democracy thrives on freedom of expression. From that point of view, there can be no justification for hindering a political group solely because it seeks to debate in public the situation of part of the State's population and to take part in the nation's political life in order to find, according to democratic rules, solutions capable of satisfying everyone concerned. ${ }^{14}$
\end{abstract}

\title{
Secularism
}

The principle of secularism is protected by a number of constitutional provisions, among which is Article 68, which provides that activities violating this principle is a cause for prohibiting a political party. The reflections of this prohibition are found in Articles 84, 85, 86, 87, 88, and 89 of the Law on Political Parties. These provisions involve the protection of Atatürk's principles and reforms (Art. 84), respect for Atatürk (Art. 85), protection of the principles of secularism and the prohibition of the advocacy of the return of khilafat (the khalif is supposed to be the temporal and spiritual head of all Muslims. The office was held by the Ottoman sultans from 1517 to 1924, when it was abolished) (Art. 86), the prohibition of the exploitation of religion and things held sacred by religion (Art. 87), prohibition of religious demonstrations (Art. 88), and the preservation of the status of the Presidency of Religious Affairs (Art.89).

Since its inception the Constitutional Court has closed down five parties on account of their alleged anti-secular activities. These are the National Order Party (20 May 1971), Turkey Peace Party (25 October 1983), Freedom and Democracy Party (23 November 1993), Welfare Party (16 January 1998), and the Virtue Party (22 June 2001). On the other hand, the Court did not rule against the Democratic Peace Movement Party, which was accused of the same violation in its ruling dated 22 May 1997. 
The Constitutional Court, in its ruling on the Freedom and Democracy Party, asserted that the party violated the Constitution by having proposed the abolition of the Presidency of Religious Affairs, although the Court also found the party guilty of having violated the national and territorial integrity of the state. The ECtHR, in its turn, reiterated its views expressed in the Socialist Party case, stating that being considered incompatible with the current principles and structures of the Turkish state does not make a proposal incompatible with the rules of democracy. ${ }^{15}$ However, the most important case for a comparative study of the Constitutional Court's and the ECtHR's approaches to party prohibitions is the Welfare Party (Refah) case, since it is the only Turkish case where the ECtHR ruled that such prohibition did not violate the principles of the European Convention.

The Constitutional Court banned the Welfare Party (WP) on 16 January 1998, on the grounds that it had become a focus of anti-secular activities. ${ }^{16}$ On 31 July 2001, a chamber of the ECtHR gave judgement that there had been no violation of the Convention. At the request of the applicants, the case was referred to the Grand Chamber, which decided unanimously on 13 February 2003 that there had been no violation of the Convention. ${ }^{17}$

The Grand Chamber first analyses in general terms the conditions under which political parties can be prohibited. It argues:

that a political party may promote a change in the law or the legal and constitutional structures of the State on two conditions: firstly, the means used to that end must be legal and democratic; secondly, the change proposed must itself be compatible with fundamental democratic principles. It necessarily follows that a political party whose leaders incite violence or put forward a policy which fails to respect democracy or which is aimed at the destruction of democracy and the flouting of the rights and freedoms recognized in a democracy cannot lay claim to the Convention's protection against penalties imposed on these grounds ... In view of the very clear link between the Convention and democracy no-one must be authorised to rely on the Convention's provisions in order to weaken or destroy the ideals and values of a democratic society. Pluralism and democracy are based on a compromise that requires various concessions by individuals or groups of individuals, who must sometimes agree to limit some of the freedoms they enjoy in order to guarantee greater stability of the country as a whole. In that context, the Court considers that it is not at all improbable that totalitarian movements, organized in the form of political parties, might do away with democracy, after prospering under the democratic regime, there being examples of this in modern European history. ${ }^{18}$

The ECtHR then discusses the conditions under which the prohibition of a political party meets a 'pressing social need', and concentrates on the following points: (i) whether there was plausible evidence that the risk to democracy, supposing it had been proven to exist, was sufficiently imminent; (ii) whether the acts and speeches of the leaders and members of the political party concerned were imputable to the party as a whole; and (iii) whether the acts and speeches imputable to the political party formed a whole which gave a clear picture of a model of society conceived and advocated by the party which was incompatible with the concept of a 'democratic society'. ${ }^{19}$ 
After that, the ECtHR then proceeds to examine whether the WP ruling of the Turkish Constitutional Court meets these criteria. The ECtHR argues that

while it can be considered, in the present case, that Refah's policies were dangerous for the rights and freedoms guaranteed by the Convention, the real chances that Refah would implement its programme after gaining power made that danger more tangible and more immediate. That being the case, the Court cannot criticise the national courts for not acting earlier, at the risk of intervening prematurely, and before the danger concerned had taken shape and become real. Nor can it criticize them for not waiting, at the risk of putting the political regime and civil peace in jeopardy, for Refah to seize power and swing into action ... in order to implement its plans. $^{20}$

The Court further reasons that the statements by Necmettin Erbakan (the party leader), Şevket Kazan and Ahmet Tekdal (two of its vice-presidents), Şevki Yılmaz, Hasan Hüseyin Ceylan, and Halil İbrahim Çelik (MPs), and Şükrü Karatepe (mayor of Kayseri) were imputable to the party as a whole. ${ }^{21}$

With regard to the grounds for prohibition, the ECtHR finds the WP's advocacy of a plurality of legal systems incompatible with democracy and quotes verbatim the reasoning of the Chamber. Thus:

the Court considers that Refah's proposal that there should be a plurality of legal systems would introduce into all legal relationships a distinction between individuals grounded on religion, would categorise everyone according to his religious beliefs and would allow him rights and freedoms not as an individual but according to his allegiance to a religious movement. The Court takes the view that such a societal model cannot be considered compatible with the Convention system, for two reasons. Firstly, it would do away with the State's role as the guarantor of individual rights and freedoms and the impartial organiser of the practice of the various beliefs and religions in a democratic society, since it would oblige individuals to obey, not rules laid down by the State in the exercise of its above-mentioned functions, but static rules of law imposed by the religion concerned.

But the State has a positive obligation to ensure that everyone within its jurisdiction enjoys in full, and without being able to waive them, the rights and freedoms guaranteed by the Convention. Secondly, such a system would undeniably infringe the principle of non-discrimination between individuals as regards their enjoyment of public freedoms, which is one of the fundamental principles of democracy. A difference in treatment between individuals in all fields of public and private law according to their religion or beliefs manifestly cannot be justified under the Convention, and more particularly Article 14 thereof, which prohibits discrimination. Such a difference in treatment cannot maintain a fair balance between, on the one hand, the claims of certain religious groups who wish to be governed by their own rules and on the other the interest of society as a whole, which must be based on peace and on tolerance between the various religions and beliefs. ${ }^{22}$

In the same vein, the Grand Chamber finds the WP's advocacy of a sharia-based government incompatible with democracy, quoting from the verdict of the Chamber, which stated that 
like the Constitutional Court, the Court considers that sharia, which faithfully reflects the dogmas and the divine rules laid down by religion, is stable and invariable. Principles such as pluralism in the political sphere or the constant evolution of public freedoms have no place in it. The Court notes that, when read together, the offending statements, which contain explicit references to the introduction of sharia, are difficult to reconcile with the fundamental principles of democracy as conceived in the Convention taken as a whole. It is difficult to declare one's respect for democracy and human rights while at the same time supporting a regime based on sharia, which clearly diverges from Convention values, particularly with regard to its criminal law and criminal procedure, its rules on the legal status of women and the way it intervenes in all spheres of private and public life in accordance with religious precepts ... In the Court's view, a political party whose actions seem to be aimed at introducing sharia in a State party to the Convention can hardly be regarded as an association complying with the democratic ideal that underlies the whole of the Convention. ${ }^{23}$

Finally, the Grand Chamber agreed with the Chamber that some statements by the WP spokesmen constituted a call for the use of violence. Thus, it is stated that

while it is true that Refah's leaders did not, in government documents, call for the use of force and violence as a political weapon, they did not take prompt practical steps to distance themselves from those members of Refah who had publicly referred with approval to the possibility of using force against politicians who opposed them. Consequently, Refah's leaders did not dispel the ambiguity of these statements about the possibility of having recourse to violent methods in order to gain power and retain it. ${ }^{24}$

As a result, the Grand Chamber ruled that the prohibition of the WP responded to a 'pressing social need' and conformed to the principle of proportionality. Thus, it found no violation of Article 11 of the Convention. ${ }^{25}$

\section{Principles to be drawn from the ECtHR decisions and the Venice Commission reports}

In the WP (Refah) and the People's Labour Party (HEP) decisions of the ECtHR, there appear to be two conditions for the prohibition of a political party. Either the party concerned must resort to violent methods or call for violence, or the political programme advocated by the party must be incompatible with democratic principles. These criteria seem reasonable and in conformity with the words and the spirit of the Convention. If one of these conditions do not materialize, the simple fact that the political project proposed by the party means a radical change in the current structure of a member state does not provide sufficient grounds for its prohibition.

These criteria appear to be somewhat different from those proposed by the Commission for Democracy through Law (Venice Commission) of the Council of Europe. In a report adopted in 1999 and entitled 'Guidelines on Prohibition and Dissolution of Political Parties and Analogous Measures', the Commisssion argues that 
prohibition or enforced dissolution of political parties may only be justified in the case of parties which advocate the use of violence or use violence as a means to overthrow the democratic constitutional order, thereby undermining the rights and freedoms guaranteed by the constitution. The fact alone that a party advocates a peaceful change of the Constitution should not be sufficient for its prohibition or dissolution.

It thus appears that the Venice criteria are even less restrictive than those of the ECtHR. In the explanatory report of the Venice Commission, it is stated that the advocacy of violence includes 'such specific demonstrations of it such as racism, xenophobia and intolerance'. This statement seems to mean that racism, xenophobia, and intolerance can be grounds for prohibition only if they involve the threat of violence, but not as independent causes of prohibition. The explanatory report also states that 'if relevant state bodies take a decision to seize the judicial body on the question of prohibition of a political party they should have sufficient evidence that there is a real threat to the constitutional order or citizens' fundamental rights and freedoms'. ${ }^{26}$

The ECtHR's ruling on the WP also contains important clues as regards the timing of the prohibition ruling. Previously, the ECtHR had argued in its ruling on the United Communist Party that the party's prohibition violated the Convention in view of the fact that the party concerned had not yet engaged in any activities. ${ }^{27}$ In its WP decision, however, the ECtHR seems to have provided a greater margin of appreciation for member states. Thus, the Court:

considers that a State cannot be required to wait, before intervening, until a political
party has seized power and begun to take concrete steps to implement a policy incom-
patible with the standards of the Convention and democracy, even though the danger
of that policy is sufficiently established and imminent. The Court accepts that where
the presence of such a danger has been established by the national courts, after
detailed scrutiny subjected to rigorous European supervision, a State may reasonably
forestall the execution of such a policy, which is incompatible with the Convention's
provisions, before an attempt is made to implement it through concrete steps that
might prejudice civil peace and the country's democratic regime.

Thus, there appears to be a very marked difference between the approaches of the Turkish Constitutional Court and the ECtHR in party prohibition cases. A number of Turkish constitutionalists have pointed out this discrepancy. According to Kaboğlu, "for the ECHR the determinant is democracy, and for the Constitutional Court the integrity of the state'. ${ }^{29}$ Arslan argues that as opposed to the 'ideologybased' paradigm of the Turkish Court, the European Court of Human Rights seems to base its decisions, at least with respect to most political party cases, on the "rights-based" paradigm that stands for a pluralist and libertarian position. ${ }^{30}$ Erdem argues in the same vein that the Turkish Constitutional Court equates behaving in accordance with the Constitution with thinking in accordance with the Constitution. The Turkish Court considers the current constitutional system of Turkey an 'absolute and immutable value' and closes down parties which 
develop a discourse incompatible with such system, whereas the ECtHR is of the opinion that such proposals cannot be considered per se incompatible with democracy, so long as they do not harm democracy itself. ${ }^{31}$

It thus appears that the Turkish Constitutional Court has given an excessively rigid interpretation to the provisions of the Law on Political Parties, itself a product of the military regime of $1980-83$, and restricted the freedom of action of political parties to a degree incompatible with democratic principles. The most marked conflict between the decisions of the ECtHR and those of the Turkish Constitutional Court is in the cases involving the protection of the territorial and national integrity of the state. On the other hand, there seems to be a degree of convergence on the question of the protection of secularism, as attested by the two Courts' decisions regarding the WP. However, this convergence does not mean that the ECtHR fully shares the Turkish Court's interpretation of secularism. For example, it is very doubtful that the ECtHR would have concurred with the Turkish Court's prohibition ruling on the Virtue Party (Fazilet Partisi, VP), since this ruling was based on the VP's efforts to secure the abolition of the headscarf ban at universities. ${ }^{32}$ It is understandable to prohibit a party for trying to impose a ban which, in itself, is incompatible with democracy. But it is certainly difficult to understand the prohibition of a political party for having tried to abolish a ban, especially one whose constitutionality is dubious.

All of the party prohibition rulings of the Constitutional Court analysed above were rendered before the constitutional amendments of 2001 and $2004 .^{33}$ Before the 2001 amendment, paragraph 3 of the Transitional Article 15 precluded the Constitutional Court from reviewing the constitutionality of laws passed during the National Security Council regime (1980-83) including, of course, the Law on Political Parties. Many Turkish constitutionalists were of the opinion, however, that the Court could have developed a more liberal interpretation of the Law on Political Parties without formally annulling it, as it did in the case of the Democratic Peace Movement Party. The 2001 constitutional amendments brought about two more improvements in the legal status of parties. One is that if the Constitutional Court establishes the violation of one the constitutional bans, it may decide to deprive the party from state funding partially or totally instead of closing it down, depending on the gravity of the violations (Art. 69, para. 7). The second is that a three-fifths majority instead of a simple majority, is required for a prohibition ruling (Art. 149, para. 1).

The abolition of paragraph 3 of the Transitional Article 15 in 2001 offers new possibilities for the Constitutional Court, which is now empowered to annul those provisions of the Law on Political Parties if it finds them unconstitutional. A second possibility is offered by the constitutional amendment of 2004, which added a new paragraph to Article 90, according to which if there is conflict between national laws and duly ratified international treaties concerning fundamental rights and liberties, international treaties shall take precedence. Obviously, this Article refers not only to the texts of the treaties, but also to judicial decisions concerning their implementation, including the decisions of the ECtHR. 
So far, the effects of these constitutional reforms on the liberalization of the political party regime in Turkey have been limited. Thus, in 2008 the Constitutional Court refused to close down HAK-PAR (Rights and Liberties Party), which advocated extensive cultural rights for the Kurdish minority similar to those recognized in such countries as Cyprus, Greece, Bulgaria, and Kosovo. The party also advocated extensive devolution of power to local authorities especially in the fields of education, health, local security, and local taxes, and the popular election of governors, sub-governors, and local security chiefs. It will be recalled that in the past such claims resulted in prohibition rulings. This time, however, the Court concluded that as long as these statements do not create an 'open and present danger' for democratic life, they should be considered within the limits of the freedom of expression. ${ }^{34}$ It has to be recalled, however, that an absolute majority of the judges (six votes) voted in favour of closure, and that HAK-PAR was saved only thanks to the 2001 constitutional amendment that required a three-fifths majority (seven votes) for closures.

The Constitutional Court was less tolerant of the AKP (Justice and Development Party), the governing party of Turkey since 2002. Similarly to the HAKPAR case, the Court refused to close down the party with six votes in favour of closure and five votes against. However, the Court decided by a one-to-ten majority that the AKP had become a focal point of anti-secular activities and deprived the party of half of its state funding for the next year. In this highly controversial ruling, the Court persisted in its rigid and authoritarian conception of secularism. Thus, the Court cited the 2008 constitutional amendment that aimed at the abolition of the headscarf ban at universities (the amendment itself was invalidated by the Constitutional Court by another controversial ruling) as the main piece of evidence for the AKP's allegedly anti-secular activities. However, the Court, citing a number of democratic reforms realized by the AKP government as attenuating circumstances and, noting that the party was not involved in any act of violence, decided to deprive it of half of its state funding instead of closing it down. ${ }^{35}$ The Court's persistence in its notion of militant secularism and the fact that both in the HAK-PAR and the AKP cases an absolute majority of the judges were in favour of closure indicate that the prohibitionist tendency of the Turkish Court is still quite strong and that the constitutional reforms of 2001 and 2004 were not sufficient to truly liberalize the political party regime in Turkey.

Another area where the Constitutional Court does not seem to have fully grasped the meaning of recent democratic reforms concerns the possibility of retrial in party prohibition cases. The Criminal Procedure Act numbered 5271 and dated 4 December 2004 (Art. 311) provides that in cases where a criminal judgement is found to be in violation of the European Convention of Human Rights by the European Court of Human Rights, this would be one of the grounds for a retrial. However, the Court rejected the application of the United Communist Party of Turkey (TBKP), banned in 1991. The closure of the TBKP was found to be in violation of the Convention by the ECtHR as was mentioned above. The Turkish Court's reasoning was that a retrial would be justified only in the existence of a new 'material fact'. ${ }^{36}$ This interpretation practically eliminates the possibility of 
a retrial on the basis of an ECtHR decision, as well as being in contradiction with the explicit intent of the Law no. 5271 that considered the ECtHR's rulings of violation an independent cause for a retrial.

A recent opinion by the Venice Commission (Commission for Democracy through Law) of the Council of Europe (CDL-AD [2009]006) adopted at its 78th Plenary Meeting on 13-14 March 2009 clearly demonstrates the still wide gap between Turkish constitutional and legal rules on party closures and the general (or best) European practice in this regard. The Commission observes that:

the most striking feature of the Turkish rules on party closure is that they combine a very long list of material criteria for prohibition or dissolution with a very low procedural threshold ... The basic problem with the present Turkish rules on party closure is that the general threshold is too low, both for initiating procedures and for prohibiting or dissolving parties. This is in itself in abstracto deviating from common European standards, and it leads too easily to action that will be in breach of the ECHR, as demonstrated in the many cases before the European Court of Human Rights. ${ }^{37}$

The Commission also observes that because of such low material and procedural thresholds,

what should be an exceptional measure functions in fact as a regular one. This reduces the arena for democratic politics and widens the scope for constitutional adjudication on political issues. The scope of democratic politics is further eroded by the constitutional shielding of the first three articles of the Constitution, in such a way as to prevent the emergence of political programmes that question the principles laid down at the origin of the Turkish Republic, even if done in a peaceful and democratic manner. ${ }^{38}$

The report ends with an invitation to Turkey 'to make the necessary amendments to the national constitution and legislation' to 'raise the general level of party protection in Turkey to that of the ECHR and the European common democratic standards ${ }^{39}$

The Venice Commission also criticizes the Turkish procedure for prohibiting parties, in that the power to start prohibition proceedings rests solely with the Chief Public Prosecutor of the Court of Cassation. The

\begin{abstract}
Commission is of the opinion that the Turkish model of giving this competence to one official - the Public Prosecutor - makes the system subject to his discretion, which is problematic since the initiation of the procedure by itself will normally be a dramatic event that may have severe impact on the political climate and may cause considerable instability ... [T] his stands in contrast to other European countries that have rules on party closure, in which - because of the exceptional nature of such cases - the decision to raise a case either rests with the democratic political institutions or at least is subject to some element of direct or indirect democratic control. ${ }^{40}$
\end{abstract}

\title{
Conclusion
}

The Constitutional Court's rulings on the AKP case and on the constitutional amendment concerning the headscarf issue clearly show that the cleavage 
between the ultra-secularists and the religio-conservatives is at present the dominant one in Turkish politics. The judiciary in general and the Constitutional Court in particular seem to have sided with the ultra-secularists front. The ruling against the AKP is clearly inspired by an exceedingly positivist and authoritarian notion of secularism with probably no parallel in any Western democracy. Similarly, the annulment of the constitutional amendment on the grounds of being against the unamendable articles of the Constitution (i.e., secularism) not only reflects the same mentality, but also amounts to a usurpation of the constituent power by the Court, since under article 148 of the Constitution the Court is allowed to exercise only a procedural, and not a substantive, review over constitutional amendments. Furthermore, the Constitution limits such review to three specific procedural defects, namely whether the amendment proposal is signed and adopted by the requisite numbers of deputies and whether it is debated twice. ${ }^{41}$

The Constitutional Court's ruling on constitutional amendments seems to have closed the door to partial amendments unless they are approved by the Court. Thus, in the spring of 2009 the AKP government seriously considered to submit a partial constitutional amendment package, which, among other things, would change the constitutional provisions on the prohibition of parties in line with the Venice criteria. However, since the main opposition party, the Republican People's Party (CHP), which is entitled under Article 150 of the Constitution to request an abstract review of it by the Court strongly opposed it, the plans were dropped. Indeed, judged by its earlier rulings on party prohibition cases, the Court would have been most likely to annul such an amendment as being against the unamendable articles of the Constitution. ${ }^{42}$ Thus, the two rulings of the Constitutional Court left the fate of further democratic reforms, including the liberalization of the constitutional rules on the prohibition of parties, uncertain. The only way out of this impasse is either to secure the cooperation of the CHP (at the moment, a distant possibility), or to revive the AKP's earlier project of an entirely new democratic constitution based on a clear and strong popular mandate.

In conclusion, there is a wide gap between Turkish rules and practices on the prohibition of political parties and the European standards developed by the ECtHR and the Venice Commission. The long list of prohibitions in the Constitution, and even more so in the Law on Political Parties, together with the low procedural threshold for initiating the prohibition cases, are further aggravated by the excessively rigid interpretations of the Turkish Constitutional Court particularly in cases that involve the territorial and national unity of the state and the principle of secularism. This is one of the most serious democratic deficits of the Turkish political system, with little likelihood of being remedied in the near future.

\section{Notes}

1. Arslan, 'Conflicting Paradigms, 11.

2. Arslan, 'Reluctantly Sailing Towards Political Liberalism', 223; along similar lines, Özbudun, 'Turkey: Plural Society and Monolithic State'. For an analysis of Turkish politics on the basis of the conflict between the state elites and the political elites, 
Heper, The State Tradition in Turkey. The exceptionality of the Turkish case has attracted a great deal of attention by constitutional law scholars and political analysts. See, for example, Can, Demokratikleşme Serüveninde Anayasa ve Siyasi Partilerin Kapatılması; Koçak and Örücü, 'Dissolution of Political Parties in the Name of Democracy'; Kogacioglu, 'Dissolution of Political Parties by the Constitutional Court in Turkey'.

3. http://www.anayasa.gen.tr/english.htm

4. Öden, Türk Anayasa Hukukunda Siyasi Partilerin Anayasaya Aykırı Eylemleri Nedeniyle Kapatılmalart, 54-8.

5. Özbudun, 'Siyasal Partiler ve Demokrasi', 22; also, Erdem, 'Türk Anayasa Mahkemesi', 255-6, 262-3.

6. Constitutional Court Decision, E. 1993/3, K. 1994/2, 16 June 1994, Anayasa Mahkemesi Kararlar Dergisi (AMKD) [Constitutional Court Reports] 2, no. 30: 1201, 1199.

7. Indeed, in a publication of the Socialist Party, the Kurds' unconditional right to selfdetermination and their rights to secede are openly acknowledged. If the Kurds decide to remain within the Republic of Turkey through a free referendum, however, the party's proposed solution is a federal system based on the equality of the Turkish and Kurdish states (Constitutional Court decision, E. 1991/2, K. 1992/1, 10 July 1992, AMKD 2, no. 28: 696-831, especially 701, 804-5).

8. European Court of Human Rights, Case of the Socialist Party and Others v. Turkey (20/1997/804) 1007, 25 May 1998, paras. 46, 47.

9. Özbudun, 'Siyasal Partiler ve Demokrasi', 23; Erdem, 'Türk Anayasa Mahkemesi', 256-8.

10. Tanör, Türkiye'de Demokratikleşme Perspektifleri, 44-5.

11. Constitutional Court decision, (Constitutional Court decision, E. 1991/2, K. 1992/1, 10 July 1992, $A M K D$ 2, no. 28 (capital letters in the original). Same views were also expressed in the Court's decision on the Freedom and Democracy Party (ÖZDEP), Constitutional Court decision, E. 1993/1, K. 1993/2, 23 November 1993, AMKD 2 no. 30 (1993): 912-13.

12. Çavuşoğlu, Uluslararası İnsan Hakları Hukukunda Azınlık Hakları, 35-9.

13. Erdem, 'Türk Anayasa Mahkemesi', 267; also, Özdek, 'Halkın Emek Partisi'nin Kapatilmasina', 200-2.

14. European Court of Human Rights, Case of Freedom and Democracy Party (ÖZDEP) v. Turkey (23885/94) (1999), ECHR 139 (8 December 1999), paras. 40, 41, 44.

15. Ibid., para. 41 .

16. Constitutional Court decision, E. 1997/1, K. 1998/1, 16 January 1998, AMKD 2, no. 34: $762-1145$.

17. European Court of Human Rights, Case of Refah Partisi (Welfare Party) and others v. Turkey. Applications nos. 41340/98, 41342/98, 41343/98 and 41344/98.

18. Ibid., paras. 98, 99 .

19. Ibid., para. 104.

20. Ibid.

21. Ibid., paras. $110-16$.

22. Ibid., para. 119.

23. Ibid., para. 123.

24. Ibid., para. 131.

25. For a critical analysis of this decision, see Erdoğan, Anayasa ve Özgürlük, 161-75. Erdoğan characterizes the ECtHR's ruling on the WP as a return to the notion of 'militant democracy'. On the other hand, the ECtHR maintained the same reasoning in its ruling on the People's Labour Party (HEP): Yazar, Karataş, Aksoy and the People's Labour Party (HEP) v. Turkey, 22723/93, ECHR 408, 9 April 2002, para. 49. 
26. Venice Commission, Guidelines on Prohibition and Dissolution of Political Parties and Analogous Measures, 1.

27. European Court of Human Rights, Case of United Communist Party of Turkey and others v. Turkey (133/1996/752/951), 30 January 1998, paras. 54, 61.

28. European Court of Human Rights, Case of Refah Partisi (Welfare Party) and others v. Turkey (see note 16 above), para. 102.

29. Kaboğlu, 'İfade Özgürlüğünün Siyasi Partilerce Kullanımının Sınırları’, 89.

30. Arslan, 'Conflicting Paradigms', 11.

31. Erdem, 'Türk Anayasa Mahkemesi', 288.

32. Constitutional Court decision, E. 1999/2, K. 2001/2, 22 June 2001, AMKD 2, no. 37 : $922-1522$.

33. On the constitutional amendments of 2001 and 2004, see Özbudun and Yazıc1, Democratization Reforms in Turkey.

34. Constitutional Court decision, E. 2002/1, K. 2008/1, 29 January 2008, Resmî Gazete (Official Gazette), 1 July 2008, no. 26923.

35. Constitutional Court decision, E. 2008/1, K. 2008/2, 30 July 2008, Resmî Gazete (Official Gazette), 24 October 2008, no. 27034. For a more detailed critique of the Constitutional Court's decision, see Özbudun, 'Anayasa Mahkemesi'nin Kırmızı Çizgileri'.

36. Constitutional Court decision, E. 2003/6, K. 2008/4, 8 January 2008, Resmî Gazete (Official Gazette), 22 March 2008, no. 26824.

37. Venice Commission, Opinion on the Constitutional and Legal Provisions, paras. 30, 107.

38. Ibid., para. 108.

39. Ibid., paras. 111, 112 .

40. Ibid., paras. 85,86 .

41. For details on the constitutional crisis of 2007-2008, see Özbudun and Faruk Gençkaya, 97-111.

42. Prime Minister Erdoğan, in a TV interview on 8 June 2009, stated that he did not want 'to relive the fate of the 411 incident' (referring to the number of votes in favour of the headscarf amendment) and that 'they would not occupy the public opinion unless there is a consensus' (on the amendment package). See Zaman (Istanbul daily), 10 June 2009.

\section{Notes on contributor}

Ergun Özbudun is Professor of Constitutional Law and Political Science at Bilkent University, Ankara, and member of the Venice Commission.

\section{Bibliography}

Arslan, Zühtü. 'Conflicting Paradigms: Political Rights in the Turkish Constitutional Court'. Critique: Critical Middle Eastern Studies 11, no. 1 (2002): 9-25.

Arslan, Zühtü. 'Reluctantly Sailing Towards Political Liberalism: The Political Role of the Judiciary in Turkey'. In Fighting for Political Freedom: Comparative Studies of the Legal Complex and Political Liberalism, eds. Terence C. Halliday, Lucien Karpik and Malcolm M. Feeley, 219-45. Oxford: Hart Publishing, 2007.

Can, Osman. Demokratikleşme Serüveninde Anayasa ve Siyasi Partilerin Kapatılması [The Constitution and the Prohibition of Political Parties in the Journey toward Democracy]. Ankara: Seçkin, 2005. 
Çavuşoğlu, Naz. Uluslararası İnsan Hakları Hukukunda Azınlık Hakları [Minority Rights in International Human Rights Law] İstanbul: Su, 2001.

Erdem, Fazıl Hüsnü. 'Türk Anayasa Mahkemesi ve Avrupa İnsan hakları Mahkemesi Kararlarında Siyasal Partilerin Kapatılması' ['The Prohibition of Political Parties in the Decisions of the Turkish Constitutional Court and the European Court of Human Rights']. Hukuk ve Adalet no. 4 (2004): 252-301.

Erdoğan, Mustafa. Anayasa ve Özgürlük [Constitution and Liberty]. Ankara: Yetkin, 2002. Heper, Metin. The State Tradition in Turkey. Walkington: The Eothen Press, 1985.

Kaboğlu, İbrahim Ö. ‘İfade Özgürlüğünün Siyasi Partilerce Kullanımının Sınırları' ['The Limits on the Exercise of Freedom of Expression by Political Parties']. Anayasa Yargısl, vol. 16. Ankara: Anayasa Mahkemesi, 1999.

Koçak, Mustafa, and Esin Örücü. 'Dissolution of Political Parties in the Name of Democracy: Cases from Turkey and the European Court of Human Rights'. European Public Law 9, no. 3 (2003): 399-423.

Kogacioglu, Dicle. 'Dissolution of Political Parties by the Constitutional Court in Turkey: Judicial Delimitation of the Political Process'. International Sociology 18, no. 1 (2003): 258-76.

Öden, Merih. Türk Anayasa Hukukunda Siyasi Partilerin Anayasaya Aykırı Eylemleri Nedeniyle Kapatılmalarl [The Prohibition of Political Parties in Turkish Constitutional Law on Account of their Unconstitutional Activities]. Ankara: Yetkin, 2003.

Özbudun, Ergun. 'Anayasa Mahkemesi'nin Kırmızı Çizgileri' ['The Red Lines of the Constitutional Court']. Zaman, (Istanbul daily), 3 November 2008.

Özbudun, Ergun. 'Siyasal Partiler ve Demokrasi' ['Political Parties and Democracy']. Siyasi Partiler ve Demokrasi Sempozyumu [Symposium on Political Parties and Democracy]. Ankara: TESAV, 1995.

Özbudun, Ergun. 'Turkey: Plural Society and Monolithic State'. Paper presented at the conference 'Democracy, Islam, and Laicism: Turkey in Comparative Perspective', Columbia University, New York, 6-7 March 2009.

Özbudun, Ergun, and Ömer Faruk Gençkaya. Democratization and the Politics of Constitution-Making in Turkey. Budapest: Central European University Press, 2009.

Özbudun, Ergun, and Serap Yazıc1. Democratization Reforms in Turkey, 1993-2004. İstanbul: TESEV, 2004.

Özdek, E. Yasemin. 'Halkın Emek Partisi'nin Kapatılmasına İlişkin Anayasa Mahkemesi Kararı Üzerine Düşünceler' ['Thoughts on the Constitutional Court's Decision to Prohibit the People's Labor Party']. Amme İdaresi Dergisi 26, no. 3 (1993): 200-2.

Tanör, Bülent. Türkiye'de Demokratiklessme Perspektifleri [Perspectives on Democratization in Turkey]. Istanbul: TÜSİAD, 1997.

Venice Commission. Guidelines on Prohibition and Dissolution of Political Parties and Analogous Measures. Venice, 10-11 December 1999, CDL-INF(2000).

Venice Commission. Opinion on the Constitutional and Legal Provisions Relevant to the Prohibition of Political Parties in Turkey. Venice, 13-14 March 2009, CDL-AD (2009)006. 